\title{
Social Status Reflected in Jane Austen's Emma
}

\author{
Mela Krismawati $^{\text {() }}$, Emil Eka Putra ${ }^{2)}$ \\ ${ }^{1}$ Universitas Putera Batam \\ melakrismawati99@gmail.com \\ ${ }^{2}$ Universitas Putera Batam \\ emil.Eka@puterabatam.ac.id
}

Received: $28^{\text {th }}$ April 2021, Revised: $5^{\text {th }}$ May 2021, Accepted: $31^{\text {st }}$ May 2021

Email Correspondence: melakrismawati99@gmail.com

\begin{abstract}
This research discusses the social status of society at Highbury in the era of 19th century. In this research the writer using qualitative method to analyze social status that reflected in Jane Austen's Emma and apply theory of Swingewood (1972), that is the sociology of literature or the sociological approach. The result of this research that obtained the social status is still upheld by the community as a culture that they must preserve. When choosing a life partner, it is often determined by the background of both parties. If both parties do not have a match in their background then their wedding will not be permanent and happy. Because a person's social status is made the key as a part of a relationship, both in love and marriage. Marriage and love relationships are motivated by social class and work. Meanwhile, based on this culture it leads to the opinion that the upper class is not worthy of having a love relationship with the lower class.
\end{abstract}

Keywords: Social status, happy, marriage and love

\section{INTRODUCTION}

In the 19th era, especially at Highbury England, there was a social status in society, which consisted of upper class people and lower class people Yuliana, Raflis and Djonnaidi (2017). Among them there are people who think that upper class people must socialize with upper class people as well. The lower class society must be with the lower class society, and the upper class society must not socialize with the lower class people who are considered not on the same level. This society's assumption has developed and has become a tradition even in weddings where someone looks for or marries their partner. In that era, for example, someone from the upper class could not get a partner from the lower class because it was considered not on the same level and vice versa Mahmud (2018). Because this assumption continues to be maintained, develops and becomes a culture in the community, choosing a partner is often determined based on their social class. Often people also give the blessing of marriage seen from their social class and cultural stratification (Saputro, setianingsih, azizah, 2018).

Online at https://journal.universitasbumigora.ac.id/index.php/humanitatis/

DOI $\quad:$ https://doi.org/10.30812/humanitatis.v7i2.1190 
The mindset of the community is what ultimately continues to develop to create a perception that in choosing a life partner you must be from an equal social class. In choosing a partner in the realm of marriage and friendship, it is still determined by social status Chan (2010 pages.55). Not only that, even when it comes to socializing in everyday life it is not appropriate for the upper class to gather or socialize with the lower class because it is considered a very taboo matter. It is from this society's mindset that the social inequality is increasingly widespread in society Hameed \& Alquraidhy (2021). They are afraid to change their own mindset because this is against the customs and customs of their ancestors from ancient times. With the belief in the culture of their ancestors, this phenomenon is still growing amid the people's mindset in that era. This mindset is also reflected in Jane Austen's Emma, which was introduced in society of Highbury, England. In this novel, the social status discussed is the matter in choosing a life partner who must be related to the culture. With the existence of a culture like this that makes socialization between communities divided because of differences in social classes. Whereas basically people grow and live permanently towards their own personal and social identities (Manstead, 2018).

This analysis uses a sociological approach by Allan Swingewood from a social document perspective. The social document is a social document which has the reflection of the situation when the work was written, covering social classes that have become a habit in society. By studying social class in society, it makes readers know the importance of sorting out the patterns of thought that become culture in the wider community, whether or not they are made into a culture (Miyamoto, 2017). From this perception, it is very sad if in social life you can differentiate between classes. It is not the meaning of the word society itself being a group of people who live in socialization and do not differentiate between class groups Santos, Grosmann and Varnum (2018). With this difference in class groups, the community relationship becomes divided and does not coalesce because of this in fact we need other people in living life Bargh \& Williams (2006). So, by doing this research to find out the reflection of social status in the novel Emma, which is describes the social situation at that time in the 19th century at Highbury.

In a social life we have our own rights to get what we want, for example in a marriage we have the right to choose our own partners, but because of the mindset that is still widespread, this social status becomes an obstacle in getting our own rights. Social status itself is defined as a condition or condition that is not balanced in social life, both personally and within groups. Sociological Approach by Allan Swingewood or sociology of literature it is use if literary works reflects social condition of society in certain period if literature is mirror of the age. Allan wrote a book sociological of literature with Diana Laurenson and famous with three perspective of SOL theory.

Three perspective of sociology of literature by Allan Swingewood: 
1. A literary work is considered a social document, that is, it reflects the situation when the literary work was written.

2. Literary work as a social condition experienced by the author.

3. Literary work as a moment that becomes history.

In this research the researcher focuses on the first perspective which is literary work as a social document. The example of social document consists of marriage, social class, occupation, stratification, housing, salary, social activities, social habits (Laurenson \& Swingewood, 1972). In the realm of marriage, the upper class must marry the upper class as well. It is not allowed for the upper class to marry the lower class because it will cause ridicule where the lower class will be considered to only want to improve their life, not based on love.

Furthermore, in the realm of social class, it is divided into 3 groups. The first is the upper class which consists of (the rich, nobles and rulers). The second is the middle class that consists of (priests and spells). The latter is the lower class consisting of (peasants and slaves). Furthermore, in the realm of occupation, someone will get their social status by seeing what their job is, such as someone who works as a farmer so that he belongs to the lower class.

In addition, in the realm of stratification, such as someone who has power, has the welfare that everyone dreams he belongs to the upper class. Whereas someone who is only a slave does not have any power even if his life is not prosperous, then that person is classified into the lower class (McGinn \& Oh, 2017). Furthermore, in the realm of housing, a person can be classified in the upper class society if that person has a large, luxurious and magnificent house. Likewise, if someone only has a rickety hut, that person is classified into the lower class. In other words, a person's social class is symbolized by a building that they have.

Further, in the realm of salary, a person is grouped into the upper class if he / she have a salary that is above average or in other words, it is enough to support his life and can also save. Unlike the case with someone who receives a salary that is only enough to eat that day, that person is classified into the lower class. Furthermore, in the realm of social activities, for example, such as someone who has classy activities such as getting education and having fun, that person is classified as the upper class group. And if their activities are limited to working as a farmer, they are classified into the lower class. The last one is the realm of social habits. For example, someone who is always dressed in luxury, eating food delicious every day, those are classified into the upper class. And on the other hand, if someone only wears the same clothes, eats just enough, then he is classified as a lower class. 
There are several previous studies that also examined Emma novel by (Austen, 1984). The first research is "The Reflection of Social Activities and Marriage Life of British Society in 19th Century as Seen in Emma by Jane Austen" written by Satria (2017). This research is discussed about social activities and marital life in the community. This study uses Allan Swingewood's theory and it is a descriptive qualitative research method. The results of this study are concluded that social class has a close relationship with marriage which can improve one's social status in the community.

The next research is "Perceptions of Marriage and Human Relationships in Jane Austen's Novel Emma written by Kica (2017). This research discussed about the customs people must use to obtain marriage. The results of this study indicate that most women marry men based on the choice of their parents and because of this it shows dissatisfaction with this tradition. Based on the previous study above, it is closely related to this research. This research and the previous research are similarity using the same data source that is Emma novel (Austen, 1984). However, this research focuses more on the social documents contained in Emma's novel.

\section{RESEARCH METHOD}

According to Creswell (2018) qualitative methods are used to analyze and identify questions such as narrative research, phenomenological research and case studies. In this study, researchers used qualitative methods in the process of collecting data, analyzing and concluding the results of the analysis. The researchers conduct observation method in the process of collecting data. First, the researchers read novel Emma carefully. The second, the researchers looking for the phenomenon that related to the theory. The third, the researchers highlights the sentence or phrase that contains the phenomenon in question. The last the researchers rewrite the data that has found and analyzes it according to the theory that the researchers applied. The results of this study explained in the form of words and sentences. In this study, researchers analyzed what the social status that reflected in the novel Emma by Austen (1984). This study apply (Swingewood (1972) theory of sociological of literature and used sociological approach.

\section{FINDING AND DISCUSSION}

\subsection{Marriage}

This utterance come from Mr. Woodhouse, he is Emma's father he said that in a relationship of marriage it can be make a change in life.

"Matrimony, as the origin of change, was always disagreeable" (Austen, 1984 Chp.1 page 11)

Online at https://journal.universitasbumigora.ac.id/index.php/humanitatis/

DOI $\quad$ : https://doi.org/10.30812/humanitatis.v7i2.1190 
This utterance describes about marriage based on thought Emma's father, that a marriage is the one agent of change in life.

This utterance comes from Emma Woodhouse, she said that a woman cannot marry a man just because she is asked to marry him, and a woman can refuse it by writing a tolerable letter.

"A woman is not to marry a man merely because she is asked, or because he is attached to her, and can write a tolerable letter". (Austen, 1984 Chp.7 page 31).

In this utterance describe character Emma, a young woman who is rich and she has the ability to turn down marriage offers. And not all women are as lucky as Emma. This utterance comes from Emma woodhouse, she said to Mr. Weston about his marriage.

"It was an unsuitable connection, and did not produce much happiness". (Austen, 1984 Chp.2 page 4) In this utterance that word "Unsuitable" because of his rich wife and poor husband, Mr. Weston's first marriage who have the same social class so there is a sense of love. In other word a marriage with different social class will not be happy and love of each other.

\subsection{Love}

There is no denying that in a relationship, a marriage, when choosing a partner, must look at the person's background, for example, what his job is and comes from his social status.

"That may be, and I may have seen him fifty times, but without having any idea of his name. A young farmer, whether on horseback or on foot, is the very last sort of person to raise my curiosity".(Austen, 1984 Chp 4. page 40)

In the above quote Emma is Harriet's best friend, when Harriet asks Emma's opinion about the man she loves. Emma said that the man was not suitable for Harriet, where Harriet was a woman who came from the upper class while the man was only a young farmer and that belonged to the lower class. Therefore, according to Emma Harriet and Martin, they have different social classes.

\subsection{House}

This utterance describes about persistence in obtaining something and over time it will come true of all.

"It was now some time since Miss Taylor had begun to influence his schemes; but as it was not the tyrannic influence of youth on youth, it had not shaken his determination of never settling till he could purchase Randalls, and the sale of Randalls was long looked forward to; but he had gone steadily on, with these objects in view, till they were accomplished. He had made his fortune, bought his house, and obtained his wife; and was beginning a new period of existence, with every probability of greater happiness than in any yet passed through". (Austen, 1984 Chp.2 page 6). 
In this utterance describe about how important getting a real home (including property) for the happiness of Mr. Weston. A happy home is a home that he owns himself. This utterance states that home is one of the most comfortable places for smart people.

"It is the greatest absurdity. The folly of not allowing people to be comfortable at home-and the folly of people's not staying comfortably at home when they can!". (Austen, 1984 Chp 13. page 24)

In the utterance describe that someone can make a house the most comfortable place for anyone that in there, and not being comfortable in a house is foolishness.

\subsection{Social status}

When this person belongs to the upper class, she is recognized and viewed by people, that is can be identified based on she is smart, charming and also has a happy life.

"Emma Woodhouse, beautiful, clever, and rich, with a comfortable home and happy disposition, seemed to unite some of the best blessings of existence; and had lived nearly twenty-one years in the world with very little to distress or vex her" (Austen, 1984 Chp 1. page 1).

It is identified that Emma is a perfect person where she is beautiful, smart and also rich. The quote above indicates Emma's social status and the house she has.

Someone who has a position as an upper class group in society, that person is highly respected and respected. When a man wants to propose to her, he must first know what kind of circle the man is, whether he is compatible with Miss Smith who comes from the upper class.

"Miss Smith is a very good sort of girl; and I should be happy to see her respectably settled. I wish her extremely well and, no doubt, there are men who might not object to every body has their level but as for myself, I am not, I think, quite so much at a loss".(Austen, 1984 Chp 3. page 200)

In the quote above Mr. Elton realizes that Miss. Smith comes from the upper class social circle, because of affection from Emma has made Harriet a respected person in these circles. Making Harriet respected among in the social community.

The work that someone does can be a part of people's opinion to classify that person into social class. Besides that, education became a very luxurious thing at that time because only upper class got education.

"I want to see you permanently well connected, and to that end it will be advisable to have as few odd acquaintance as may be; and, therefore, I say that if you should still be in this country when Mr. Martin marries, I wish you may not be drawn in by your intimacy with the sisters, to be acquainted with the wife, who will probably be some mere farmer's daughter, without education". (Austen, 1984 Chp 4. Page 43) 
From the quote above Emma thinks that if Harriet accepts Mr. Martin ate that their marriage would not be eternal or would only last a moment because they both came from different backgrounds, namely Mr. Martin is only a farmer and does not have the education like a Ms. Harriet.

Emma always views a relationship with an equal background. She matches Harriet to several men who have the same social status as Harriet, because according to Emma, a happy relationship is a relationship that comes from the same social status.

"What say you to Mr. Weston and Mr. Elton? Compare Mr. Martin with either of them. Compare their manner of carrying themselves; of walking; of speaking; of being silent. You must see the difference. Which makes his good manners the more valuable. The older a person grows, Harriet, the more important it is that their manners should not be bad". (Austen, 1984 Chp 4. Page 46)

In the quote above Emma thinks that Mr. Martin is not suitable for Harriet, therefore Emma matches up some of her male friends who have the same social status as Harriet, unlike Mr. Martin who comes from a lower class social status.

\section{CONCLUSION}

Discussing social status in the community cannot be denied where the background of that person, such as based on that person's job, salary, house, and even in his style of dress. In Jane Austen's novel Emma it is very complex to discuss social status. There are 4 types of social status found in this novel that are starting from a relationship between marriage, love, house, and social status. When choosing a life partner, it is often determined by the background of both parties. If both parties do not have a match in their background then their wedding will not be permanent and happy. Because a person's social status is made the key as a part of a relationship, both in love and marriage.

In this novel, it is explained that when you want to have a relationship you must have an equal background, namely the upper class must be with the upper class and the upper class cannot marry the lower class because it is believed that marriage will not bring happiness. This novel is very depicting a situation where in the era of the 19th century the people still highly upheld their culture towards social status. With this research, it helps readers to know the history of this era and the types of social status. 


\section{REFERENCES}

Austen, J. (1984). Emma (Third). Bantam Classics.

Bargh, J. A., \& Williams, E. L. (2006). The automaticity of social life. Current Directions in Psychological Science, 15(1), 1-4. https://doi.org/10.1111/j.0963-7214.2006.00395.x

Chan, T. W. (2010). Social Status and Consumption. (T. W. Chan, Ed.). New York: Cambridge University Press.

Creswell, J. W., \& David, J. (2018). Research Design: Qualitative, Quantitative, and Mixed Methods Approaches. In D. C. Felts (Ed.) (fifth edit). United State of America: Sage Publication.

Febryanti, N. K., Hadi, M. Z. P., \& Hastuti, H. (2019). An Analysis of Code-switching Used in 'The Architecture of Love' Novel Written by Ika Natassa. Humanitatis, 6(1), 109-118.

Hameed, K. A., \& Alquraidhy, M. S. (2021). Evolutionary love and companionate marriage in Jane Austen's nove Pride and Prejudice. International Journal of Language and Literary Studies, 3(1), 105-121.

Kica, E. (2017). Perceptions of Marriage and Human Relationships in Jane Austen's Novel Emma. European Scientific Journal, ESJ, $13(32), \quad 65$. https://doi.org/10.19044/esj.2017.v13n32p65

Laurenson, D., \& Swingewood, A. (1972). The Sociology of Literature. London: Paladin.

Mahmud, F. S. (2018). Analysis of love by using tringular theory of love by Sternberg in Breaking Down novel by Stephenie Meyer. Journal Bahasa Dan Sastra Inggris, 7(1), 2842.

Manstead, A. S. R. (2018). The psychology of social class: How socioeconomic status impacts thought, feelings, and behaviour. British Journal of Social Psychology, 57(2), 267-291. https://doi.org/10.1111/bjso.12251

McGinn, K. L., \& Oh, E. (2017). Gender, social class, and women's employment. Current Opinion in Psychology, 18, 84-88. https://doi.org/10.1016/j.copsyc.2017.07.012

Miyamoto, Y. (2017). Culture and social class. Current Opinion in Psychology, 18, 67-72. https://doi.org/10.1016/j.copsyc.2017.07.042

Santos, H. C., Grossmann, I., \& Varnum, M. E. W. (2018). Class, cognition and cultural change in social class.

Saputro, G. Y., Setianingsih, F., \& Azizah, K. M. (2018). When class defines art and marriage approval: A marxist analysis of The Greatest Showman. Jurnal Ilmiah Lingua Idea, 9(2), $121-128$.

Satria, R. (2017). The reflection of social activities and marriage life of british society in 19th century as seen in Emma by Jane Austen. JOURNAL BASIS, 4(1), 11-24.

Yuliana, S. M., Raflis, \& Djonnaidi, S. (2017). The social impact toward a north carolina man as seen in Nicholas Sparks' The Notebook. Jurnal Ilmiah Langue and Parole, 1(1), 191-199. https://doi.org/10.36057/jilp.v1i1.20 